Research Article

\title{
Chromosomal variability in Brazilian species of Anthurium Schott (Araceae): Heterochromatin, polyploidy, and B chromosomes
}

\author{
Sarah do Nascimento ${ }^{1}$, Marcus Alberto Nadruz Coelho ${ }^{2}$, Joel M. P. Cordeiro ${ }^{1}$ and Leonardo P. Felix ${ }^{1}$ (iD \\ ${ }^{1}$ Laboratório de Citogenética Vegetal, Departamento de Ciências Biológicas, Centro de Ciências Agrárias, \\ Universidade Federal da Paraíba, Areia, PB, Brazil. \\ ${ }^{2}$ Instituto de Pesquisas, Jardim Botânico do Rio de Janeiro, Ministério do Meio Ambiente, Rio de Janeiro, \\ RJ, Brazil.
}

\begin{abstract}
The genus Anthurium has a Neotropical distribution, with karyotype predominance of $x=15$, although some species show disploidy or polyploid variations. The karyotypes of seven species and different populations of Anthurium were analyzed using fluorochrome CMA and DAPI staining. The karyotypes were composed of meta- and submetacentric chromosomes, with numbers varying from $2 n=30$ to $2 n=60$. Supernumerary euchromatic chromosomes were observed in $A$. affine, and supernumerary heterochromatic chromosomes were observed in $A$. gladiifolium and $A$. petrophilum. Polyploidy was recurrent in the Anthurium species analyzed, with records of $2 n=30$ and 60 in different A. pentaphyllum populations. Fluorochrome staining revealed different $\mathrm{CMA}^{+}$banding distributions between diploid and polyploid cytotypes of $A$. pentaphyllum, suggesting structural alteration events. Anthurium petrophilum, on the other hand, showed a more consistent banding profile, with 10 to 12 proximal CMA bands in the three populations analyzed. $\mathrm{DAPI}^{+} / \mathrm{CMA}^{0}$ regions occurred exclusively in populations of $A$. gracile and $A$. pentaphyllum. The heterochromatic fraction in Anthurium was found to be quantitatively variable among species and populations, which may be related with adaptive aspects, different environmental conditions, or phylogenetic position.
\end{abstract}

Keywords: B chromosomes, CMA/DAPI, cytotaxonomy, Neotropical Araceae.

Received: March 23, 2018; Accepted: February 15, 2019.

\section{Introduction}

The genus Anthurium is a strictly Neotropical monophyletic group that occurs from Mexico to Argentina, and is included within the subfamily Pothoideae, tribe Potheae (Croat, 1986; Coelho et al., 2009; Cusimano et al., 2011; Carlsen and Croat, 2013; Govaerts et al., 2016). This group comprises approximately 950 species (Boyce and Croat, 2011 onwards), 134 of which are known in Brazil (Coelho et al., 2018). The genus is taxonomically complex and subdivided into 18 sections (Croat and Sheffer, 1983) showing wide intra- and interspecific morphological diversity (Coelho and Mayo, 2007). The plants can have a terrestrial habit in the case of forest species, or be rupiculous, epiphytic, or hemiepiphytic vines, but they are rarely found in aquatic environments (Coelho et al., 2009; Gonçalves and Jardim, 2009); there are numerous helophytic species that can be found growing on exposed rock surfaces (Gonçalves, 2005; Haigh et al., 2011). The genus is monophyletic, with 18 clades that are easily distinguishable morphologically or

Send correspondence to Leonardo P. Felix. Centro de Ciências Agrárias, Universidade Federal da Paraíba, Campus II, Rodovia PB 079, km 12, 58397-000 Areia, PB, Brazil. E-mail: Ipfelix2@gmail.com. geographically, and show low divergence in their $\operatorname{trn} G$ intron, $t r n H-p s b A$ and $t r n C-y c f 6$ sequences, and in the $C H S$ intron regions of their DNA, suggesting a rapid radiation of the group (Carlsen and Croat, 2013).

Chromosomal records have been published for approximately 150 Anthurium species, with a predominance of $2 n=30$ ( $88 \%$ of the species), but numbers vary from $2 n=$ 24 to $2 n=124$ (Sheffer and Croat, 1983; Petersen, 1989; Rice et al., 2015). The genus is notorious for the occurrence of intraspecific polyploidy, such as A. bellum Schott with $2 n=30,90$ (Sheffer and Croat, 1983; Cotias-de-Oliveira et al., 1999), A. pentaphyllum G.Don with $2 n=30,60$ (Cotias-de-Oliveira et al., 1999), and A. digitatum (Jacq.) G.Don with $2 n=30,60$ (Rice et al., 2015). Six species from southeastern and southern Brazil were analyzed and intraspecific polyploidy was observed in three of them, with the predominance of diploid cytotype, as in A. urvilleanum Schott and A. harrisii G.Don, or the predominance of tetraploid cytotype, as in $A$. intermedium Kunth (Viégas et al., 2006). B chromosomes also occur frequently and have been observed in both diploid and tetraploid samples. A population of $A$. urvilleanum, close to Paratí, Rio de Janeiro State, Brazil (M. Nadruz, 1543), showed $2 n=30+0-2$ Bs, while another population within the same municipality (M. Na- 
druz, 1394) showed $2 n=60+0-2 B$ s (Viégas et al., 2006). In spite of the frequent presence of $\mathrm{B}$ chromosomes in Anthurium, they are not easily distinguishable based on size and shape, or methodology employed.

The most complete study of B chromosomes in Anthurium was undertaken by Marutani and Kamemoto (1983), and included examining both somatic and meiotic cells in A. warocqueanum Moore. These authors observed that the numbers of $\mathrm{B}$ chromosomes in somatic cells in the species was constant $(2 n=30+3 \mathrm{~B})$, although there were different associations during metaphase I of meiosis (one trivalent, one bivalent and one univalent, or three univalents), resulting in variable numbers of B chromosomes in selfed offspring (ranging from 0 to 6) and indicating their transmission from both male and female gametes. The diversity of B chromosomes in Anthurium was noted by Marutani et al. (1993), who reported them in A. ochranthum K.Koch, A. cerrocampanense Croat, and A. garagaranum Standl., as well as in at least six interspecific hybrids resulting from crosses between $A$. kamemotoanum Croat A. ochranthum, A. lindenianum K.Koch \& Augustin A. cerrocampanense, A. garagaranum A. lindenianum, $A$. cerrocampanense $A$. garagaranum, $A$. formosum Schott A. cerrocampanense, and A. subsignatum Schott A. garagaranum.

B chromosomes are commonly heterochromatic, although they appear euchromatic in some species (Camacho et al., 2000; Banaei-Moghaddam et al., 2014). No differential staining of Anthurium chromosomes has yet been undertaken, and the chromatin compositions of B chromo- somes among its different species have not been examined. We therefore analyzed chromosome number variability and CMA/DAPI banding distributions in seven Brazilian species of Anthurium to identify interspecific variations and supernumerary chromosomes in different populations and cytotypes. The main objective of this work was to identify karyotype variability in Brazilian species of Anthurium to determine the importance of that variability to chromosome evolution in the genus.

\section{Materials and Methods}

\section{Collections and botanical documentation}

Seven species of Anthurium harvested in various regions of Brazil were investigated, including individuals from three different populations. Intraspecific variations were investigated in four of the seven species. Information concerning all of the samples and their respective collection localities, populations, and collectors are summarized in Table 1. Specimens were maintained alive in the experimental gardens of the Plant Cytogenetic Laboratory of the Department of Biological Sciences of the Agrarian Sciences Center at the Federal University of Paraíba (UFPB), Brazil. Exsiccates were deposited in the Prof. Jayme Coelho de Moraes Herbarium (EAN).

\section{Chromosomal analyses}

Root tips were pretreated with $0.2 \%$ colchicine for 24 $\mathrm{h}$ at $10 \mathrm{C}$, fixed in 3:1 ethanol - acetic acid (v:v) for $2 \mathrm{~h}$ at room temperature, and subsequently stored at $-20 \mathrm{C}$ until

Table 1 - The Anthurium species analyzed, citing their origins, voucher numbers, chromosome numbers, CMA/DAPI bands, and figures.

\begin{tabular}{|c|c|c|c|c|c|}
\hline Genus/species & Voucher & Origin (city/state) & $2 n$ & CMA bands & Figures \\
\hline \multirow[t]{5}{*}{ Anthurium affine Schott } & LPFelix 14635 & Queimadas, PB & $30+1 B$ & $2 \mathrm{p}$ & $1 \mathrm{~A}$ \\
\hline & EMAlmeida 453 & Águas Belas, PE & 30 & $1 \mathrm{p}$ & 1B \\
\hline & & & $30+2 B$ & $2 \mathrm{p}$ & $1 \mathrm{C}$ \\
\hline & EMAlmeida 476 & Andaraí, BA & 30 & $2 \mathrm{p}$ & $1 \mathrm{D}$ \\
\hline & & & $30+3 B$ & $2 \mathrm{p}$ & $1 \mathrm{E}$ \\
\hline A. gladiifolium $\mathrm{Schott}$ & JPCastro 40 & Jacobina, BA & $30+3 B$ & $12 \mathrm{p}$ & $1 \mathrm{~F}$ \\
\hline \multirow[t]{3}{*}{ A. gracile Lindl. } & JPCastro 61 & Senhor do Bonfim, BA & 30 & $10 \mathrm{p}$ & $1 \mathrm{G}$ \\
\hline & LPFelix 13662 & Mamanguape, PB & 40 & $2 \mathrm{p}$ & $1 \mathrm{H}$ \\
\hline & LPFelix 14865 & Peruíbe, SP & 40 & $2 \mathrm{p}$ & $1 \mathrm{I}$ \\
\hline A. jilekii Schott* & LPFelix 13761 & Taquaritinga do Norte, PE & 30 & $2 \mathrm{p}$ & $2 \mathrm{~A}$ \\
\hline \multirow[t]{3}{*}{ A. pentaphyllum G.Don } & LPFelix 15074 & Meruoca, CE & 30 & $13 p$ & 2B \\
\hline & LPFelix 13663 & Mamanguape, PB & 60 & $5 p$ & $2 \mathrm{C}$ \\
\hline & LPFelix 14871 & Itabaiana, SE & 60 & $3 p$ & $2 \mathrm{D}$ \\
\hline \multirow[t]{3}{*}{ A. petrophilum K.Krause* } & LPFelix 12614 & Buíque, PE & 30 & $10 p$ & $2 \mathrm{E}$ \\
\hline & EMedeiros-Neto 22 & Brejo da Madre de Deus, PE & 30 & $12 \mathrm{p}$ & $2 \mathrm{~F}$ \\
\hline & SNascimento 150 & São João do Tigre, PB & $30+1 B$ & $12 \mathrm{p}$ & $2 \mathrm{G}$ \\
\hline Anthurium sp. & LPFelix 15273 & São Roque de Minas, MG & 30 & $2 \mathrm{p}$ & $2 \mathrm{H}$ \\
\hline
\end{tabular}

* First chromosome count for the species

$\mathrm{PB}=$ Paraíba, $\mathrm{PE}=$ Pernambuco, $\mathrm{BA}=$ Bahia, $\mathrm{CE}=$ Ceará, $\mathrm{SE}=$ Sergipe, $\mathrm{MG}=$ Minas Gerais State, Brazil. $\mathrm{p}=$ pericentromeric bands 
analyzed. The material was then washed in distilled water and digested in an enzymatic solution containing $2 \%$ cellulase (Onozuka) and 20\% pectinase (Sigma) (w/v) for 1 $\mathrm{h}$ at $37^{\circ} \mathrm{C}$. Slides were prepared using the squashing method in a drop of $45 \%$ acetic acid. Coverslips were subsequently removed in liquid nitrogen and samples were then air dried and kept for three days at room temperature (Guerra and Souza, 2002).

Fluorochrome staining followed the protocol described by Carvalho et al. (2005). Samples were stained with $10 \mu \mathrm{L}$ chromomycin A3 (CMA) $(0.1 \mathrm{mg} / \mathrm{mL})$ and stored for $1 \mathrm{~h}$ in the dark, before staining with $10 \mu \mathrm{L}$ de DAPI $(2 \mu \mathrm{g} / \mathrm{mL})$, were again stored in the dark for $30 \mathrm{~min}$ before mounting with glycerol/Mcllvaine. The slides were aged for three days in the dark to stabilize the fluorochromes. Metaphases were photographed using a AxioCam MRm epifluorescence microscope (Zeiss) equipped with a video camera, utilizing Axiovision 4.8 software (Zeiss). Images were processed using Adobe Photoshop CS3 Software (Adobe Systems). Chromosome measurements were made using Image Tool 3.0 software (Brent et al., 2008). Chromosome morphology was determined using the centromeric index, following Guerra (1986a).

\section{Results}

Chromosome numbers and heterochromatin characteristics are summarized in Table 1. All species exhibited symmetrical karyotypes, with chromosomes varying from submetacentric to metacentric (Figures 1 and 2). Chromosome numbers varied from $2 n=30$ to $2 n=60$, with most species showing $2 n=30 ; 2 n=40$ was observed in two populations of $A$. gracile (Figure 1H, I) and $2 n=60$ in two populations of $A$. pentaphyllum (Figures 2C-D). Euchromatic $\mathrm{B}$ chromosomes were observed in a population of $A$. affine Schott from Queimadas, Paraíba State (Figure 1A), and in populations from Águas Belas, Pernambuco State (Figure 1C) and Andaraí, Bahia State (Figure 1E). Anthurium gladiifolium Schott, on the other hand, showed three heterochromatic B chromosomes (Figure 1F), while the population of $A$. petrophilum K.Krause from São João do Tigre, Paraíba, showed a single heterochromatic B chromosome (Figure 2G). The species of Anthurium with B chromosomes analyzed here, their respective populations, and the frequency of B chromosomes in mitotic cells are presented in Table 2. None of the other species exhibited supernumerary chromosomes.

Staining with fluorochromes revealed from one to two proximal $\mathrm{CMA}^{+} / \mathrm{DAPI}^{-}$bands on the short arm of $A$. affine (Figure 1A-E), in two populations of $A$. gracile Lindl. with $2 n=40$ (Figure 1H-I), in A. jilekii Schott (Figure 2A), and in Anthurium sp. (Figure $2 \mathrm{H}$ ). The population of $A$. gracile from Senhor do Bonfim, Bahia $(2 n=30)$ showed up to 10 conspicuous proximal CMA bands (Figure 1G), while A. gladiifolium showed up to 12 proximal bands (Figure $1 \mathrm{~F}$ ), and up to $13 \mathrm{CMA}$ bands were seen in a diploid population of $A$. pentaphyllum (Figure 2B). The tetraploid popu- lations of $A$. pentaphyllum examined, however, exhibited five proximal CMA bands in a population from Mamanguape, Paraíba (Figure 2C) and three bands in a population from Itabaiana, Sergipe (Figure 2D). Anthurium petrophilum, on the other hand, demonstrated a more consistent banding profile, with 10 to 12 proximal CMA bands in the three populations analyzed. $\mathrm{DAPI}^{+} / \mathrm{CMA}^{-}$bands were not clearly observed, except in the $A$. gracile population from Peruíbe (Figure 1I) and in A. pentaphyllum from Meruoca (Figure 2B), where the terminal regions of some chromosomes appeared stained with DAPI rather than with CMA, which were interpreted as $\mathrm{DAPI}^{+} / \mathrm{CMA}^{0}$ regions.

\section{Discussion}

\section{Numerical chromosome variations}

Of the seven species analyzed here, our results confirmed previous counts for $A$. pentaphyllum with $2 n=30$ and 60 (Cotias-de-Oliveira et al., 1999), A. gracile with $2 n$ $=30$ and 40 (Sheffer and Kamemoto, 1976; Guerra, 1986b), and $A$. gladiifolium and $A$. affine with $2 n=30$ (Sheffer and Kamemoto, 1976; Carvalheira et al., 1991; Cotias-de-Oliveira et al., 1999). The counts for A. jilekii and A. petrophilum, both with $2 n=30$, are new.

The chromosome number $2 n=30$ is the most frequent in the genus Anthurium, although other chromosome numbers, such as $2 n=26,28,32,36$, and 40, also occur (Sheffer and Kamemoto, 1976; Sheffer and Croat, 1983; Viégas et al., 2006). Those variations may represent cases of ascending or descending disploidy or different euploidy series of $n$ $=15$. Similarly, reports of polyploidy generally follow two distinct models ( $2 n=30-60-90$ and $2 n=28-56)$ (Sheffer and Croat, 1983; Viégas et al., 2006). Among the polyploid species analyzed, A. pentaphyllum follows the 30-60-90 model, the most common in the genus (Sheffer and Croat, 1983). In the $2 n=30,40$ and 60 series reported for $A$. gracile (Sheffer and Croat, 1983; Guerra, 1986b; present work), however, $2 n$ $=40$ may have resulted from ascending or descending disploidy, although there are no intermediate chromosome numbers in the literature in support of those events.

Polyploidy and disploidy are among the most important karyotype phenomena associated with the evolution of plant groups (Stebbins, 1971; Soltis et al., 2014). Species showing disploidy and polyploidy tend to be morphologically distinct from their parental diploids, and can present adaptations to different habitats and ecological niches (Madlung, 2013; Ramsey and Ramsey, 2014; Cordeiro et al., 2018; Scholthof et al., 2018). However, the occurrence of disploidy or polyploidy in Anthurium does not appear to have any apparent ecological correlation or link to their geographic distributions, although they may have considerable effects on speciation within the genus, especially in the species $A$. scandens (Aubl.) Engl. $(2 n=24,48,84), A$. digitatum (Jacq.) G.Don $(2 n=26,30,36,40,60)$, and $A$. bellum Schott $(2 n=28,56,90)$ (Sheffer and Kamemoto, 1976; Rice et al., 2015). 


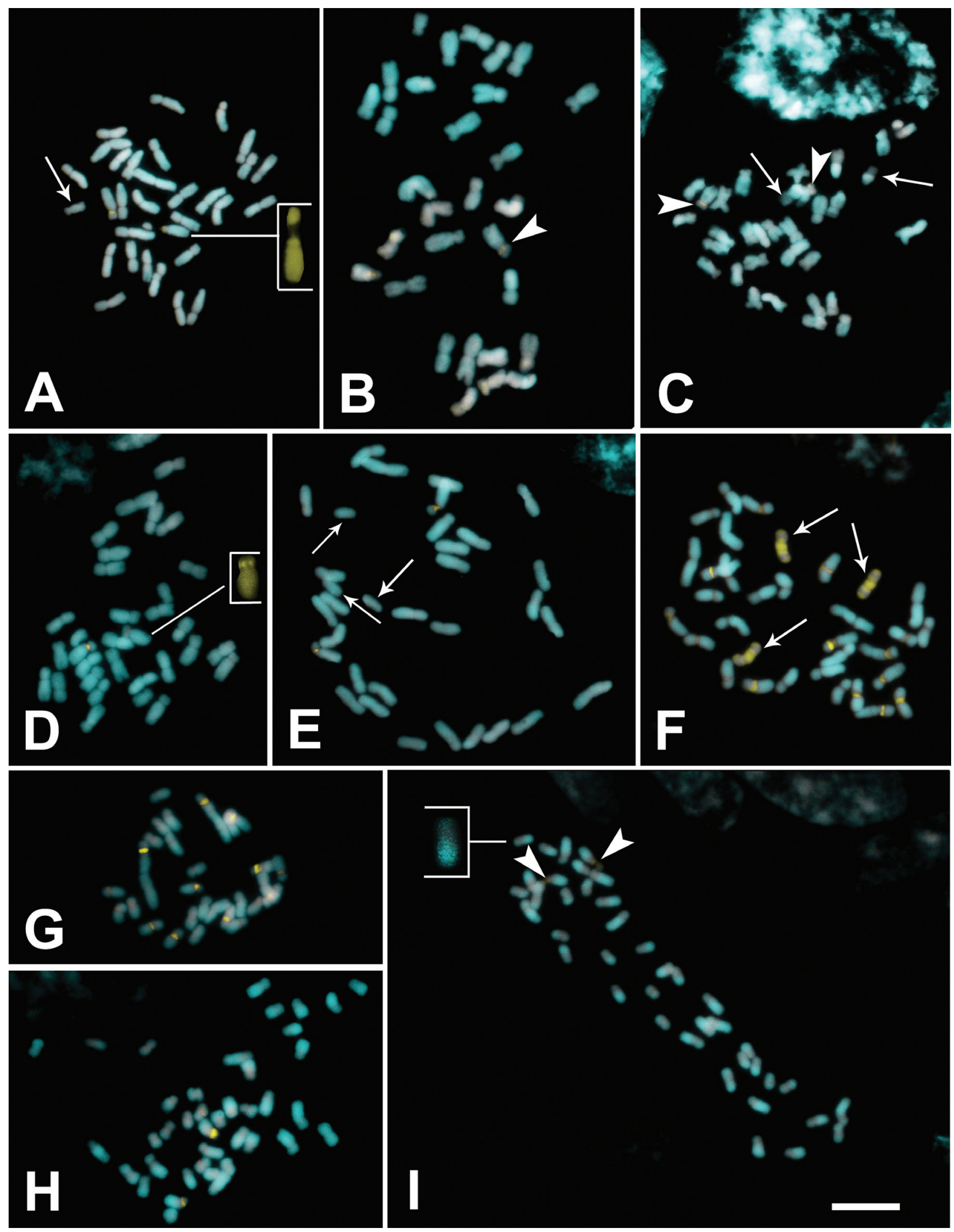

Figure 1 - Metaphases of Anthurium species under CMA/DAPI staining. (A-E) Anthurium affine. (A) Queimadas-PB population with $2 n=30+1 \mathrm{~B}$; (B-C) Águas Belas-PE population, with $2 n=30$ (B) and $2 n=30+2 \mathrm{Bs}(\mathrm{C})$; (D-E) Andaraí-BA population with $2 n=30$ (D) and $2 n=30+3 \mathrm{Bs}(\mathrm{E})$; (F) $A$. gladiifolium $(2 n=30+3 \mathrm{Bs})$; (G-I) A. gracile. Senhor do Bonfim-BA population with $2 n=30(\mathrm{G})$, Mamanguape-PB (H) and Peruíbe-SP population (I), both with $2 n=40$. Arrows in A, C, E and F show B chromosomes; arrow heads in B, C and I show minor CMA bands; inserts in A and D highlight chromosomes with CMA bands; inserts in I show chromosomes with $\mathrm{DAPI}^{+} / \mathrm{CMA}^{0}$ blocks. Bar in I is equivalent to $10 \mu \mathrm{m}$. 
The basic number $x=15$ appears as the most probable for Anthurium based on the wide occurrence of $2 n=30$ in the genus (Marchant, 1973). Sheffer and Kamemoto (1976) and Sheffer and Croat (1983) suggested $x=12$ as the basic
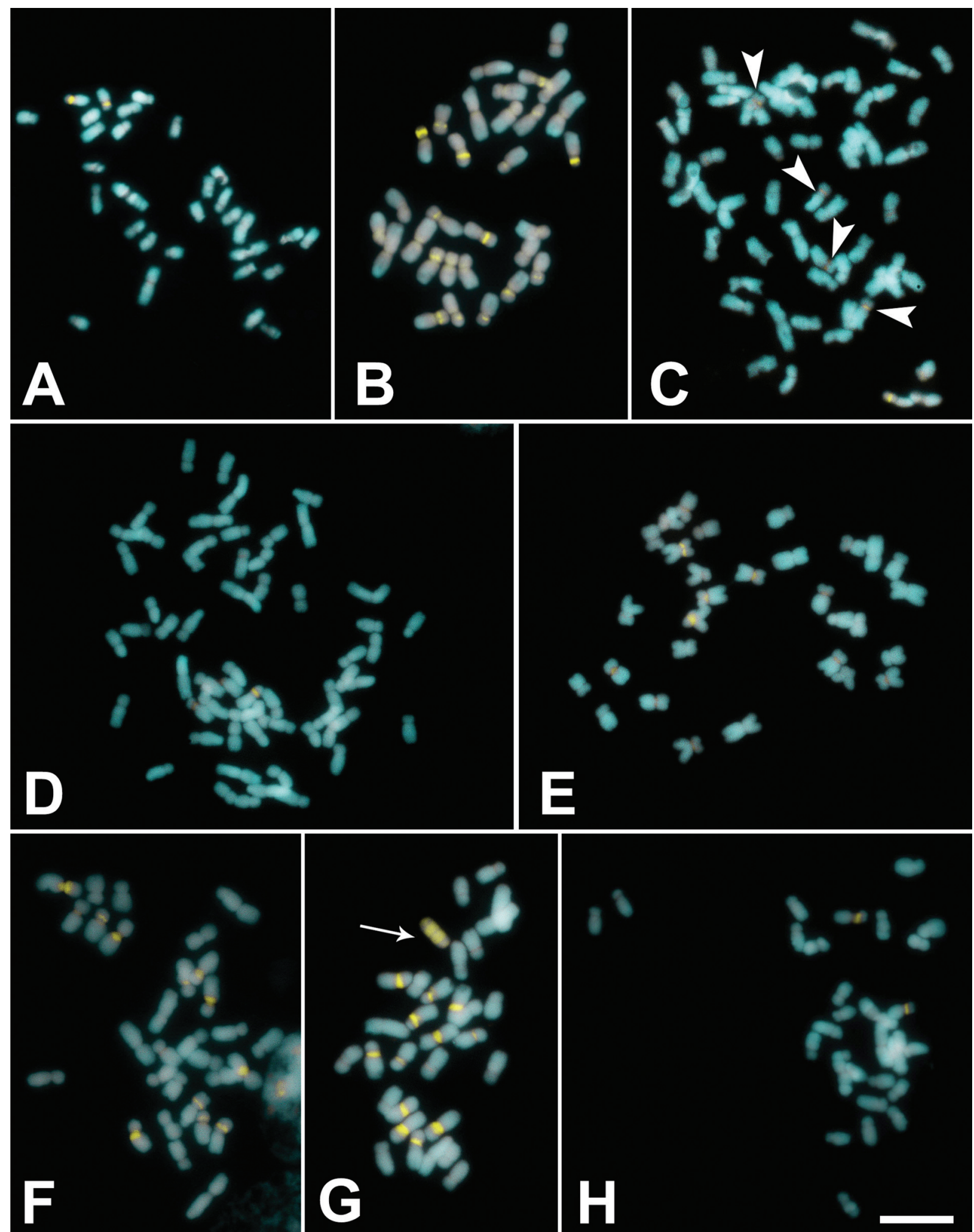

Figure 2 - Metaphases of Anthurium species under CMA/DAPI staining. (A) Anthurium jilekii with 2n=30; (B-D) A. pentaphyllum, Meruoca-CE population with $2 n=30$ (B), Mamanguape-PB (C) and Itabaiana-SE populations (D), both with $2 n=60 ;$ (E-G) A. petrophilum, Buíque-PE population (E) and Brejo da Madre de Deus-PE population (F), with $2 n=30$ and São João do Tigre-PE population (G) with $2 n=30+1 \mathrm{~B} ; \mathrm{H}$. Anthurium sp. (2n=30). Arrows in $\mathrm{G}$ show B chromosomes; arrow heads in $\mathrm{C}$ show chromosomes with CMA bands. Bar in $\mathrm{H}$ is equivalent to $10 \mu \mathrm{m}$. 
Table 2 - Anthurium species with B chromosomes and their frequencies of occurrence in mitotic cells.

\begin{tabular}{|c|c|c|c|c|}
\hline Species & Origin (city/state) & Total number of analyzed cells & $2 n$ & Frequency absolute (relative) \\
\hline \multirow[t]{5}{*}{ Anthurium affine } & Queimadas, PB & 13 & $30+1 B$ & $13(100 \%)$ \\
\hline & Águas Belas, PE & 15 & 30 & $9(60 \%)$ \\
\hline & $30+2 B$ & $6(40 \%)$ & & \\
\hline & Andaraí, BA & 30 & 30 & $11(36.7 \%)$ \\
\hline & $30+3 B$ & $19(63.3 \%)$ & & \\
\hline A. gladiifolium & Jacobina, BA & 31 & $30+3 B$ & $31(100 \%)$ \\
\hline A. petrophillum & São João do Tigre, PB & 35 & $30+1 \mathrm{~B}$ & $35(100 \%)$ \\
\hline
\end{tabular}

ancestral number due to records of $2 n=24$ and 48 in species of the section Tetraspermium Schott. Molecular phylogenetic data nonetheless suggest that the section Tetraspermium occupies a derived position in the genus (Carlsen and Croat, 2013). Anthurium flexile Schott, with $2 n=60$ (Sheffer and Kamemoto, 1976), and A. clidemioides Standl. with $2 n=30$ (Petersen, 1989) have been considered the most basal species (Carlsen and Croat, 2013), in support of $x=15$ as the basic number of Anthurium. However, the hypothesis of $x=12$ cannot be discarded offhand, as species of the genus Pothos L. (a sister group to Anthurium) show $2 n=24$ and 26 (Rice et al., 2015), suggesting a relationship of those numbers to the karyotypic evolution of Anthurium.

\section{B chromosomes}

Of the 153 species of the genus Anthurium with known chromosome numbers, B chromosomes have been identified in 20 (approximately 13\%). Among the species found to have $\mathrm{B}$ chromosomes, there are records for $A$. affine (Cotias-de-Oliveira et al., 1999) and the new occurrences in $A$. gladiifolium $(30+3 \mathrm{Bs})$ and $A$. petrophilum $(30+1 B)$. However, the occurrence of B chromosomes in the genus may be underestimated, whereas the numbers of $\mathrm{B}$ chromosomes may have been interpreted as intraspecific disploidy variation in chromosome numbers. For example, A. obtusum (Engl.) Grayum with $2 n=24,30$, A. durandii Engl. with $2 n=28,30$ (Sheffer and Croat, 1983), and $A$. conspicuum Sodiro with $2 n=28,32$ (Rice et al., 2015) may reflect $\mathrm{B}$ chromosomes interpreted as A chromosomes.

The B chromosomes of Anthurium, besides varying in number, can also vary in their origin and chromatin composition. Anthurium affine is distinct from other species because its B chromosomes were euchromatic, while $A$. gladiifolium and $A$. petrophilum show $\mathrm{B}$ chromosomes composed principally of GC-rich heterochromatin. Anthurium affine is characterized by having only small quantities of GC-rich heterochromatin, which are observed only in the NORs of one or two chromosomes. Anthurium gladiifolium and A. petrophilum, on the other hand, show large CMA bands in the pericentromeric regions of five to six chromosome pairs. Although the origins of B chromosomes are not yet certain, one well-accepted hypotheses is their derivation from A chromosomes (Jones and Houben, 2003; Houben et al., 2013). In that sense, it is reasonable to suppose that GC-rich heterochromatin regions of the A chromosomes of $A$. gladiifolium and $A$. petrophilum were incorporated into (and amplified in) their B chromosomes.

The occurrence of B chromosomes in Anthurium, as well as other groups of plants, seems to be independent phenomena (Camacho et al., 2000; Levin et al., 2005), without any clear effects above the species level. Phylogenetic analyses corroborate that hypothesis, as one can see in Anthurium species that have $\mathrm{B}$ chromosomes, but are placed in different clades (see the phylogenetic hypothesis proposed by Carlsen and Croat, 2013). As in Anthurium, the occurrences of B chromosomes in Picea A.Dietr. (Pinaceae) do not show clear phylogenetic relationships (Lockwood et al., 2013). All of the species of Calochortus Pursh (Liliaceae) that have B chromosomes (D'Ambrosio et al., 2017), on the other hand, are in the same clade (Subsection Venusti, Patterson and Givnish, 2003), suggesting that the occurrence of B chromosomes in different plants reflects different causes.

The presence of B chromosomes can produce phenotypic effects at the level of individuals, especially related to vigor, fertility and fecundity, increased germination vigor or speed, or the appearance of morphological traits (leaf striping in maize, for example) (Camacho et al., 2000; Banaei-Moghaddam et al., 2014; Houben et al., 2014). Studies involving correlations of B chromosomes and ecological/adaptive aspects will be extremely important to the understanding of their evolutionary relationships in plants, making Anthurium an excellent genus for testing hypotheses.

\section{Heterochromatin in Anthurium}

Heterochromatin distribution appears to be relatively variable among different species and populations of Anthurium. Heterochromatin is most frequently located in the subtelomeric and pericentromeric regions of plant chromosomes and in NORs (Lamb et al., 2007). Heterochromatin associated with NORs in plants frequently appears as $\mathrm{CMA}^{+} / \mathrm{DAPI}^{-}$bands (Guerra, 2000). Those sequences can be differentially amplified, forming characteristic patterns useful in differentiating between the karyotypes of closely related taxa, such as in Citrus L. (Carvalho et al., 2005), Acianthera Scheidw. (Oliveira et al., 2015), the Bignonieae tribe (Cordeiro et al., 2017), Spondias L. (Almeida et al., 
2007), Ameroglossum Eb. Fisch., S. Vogel \& A.V.Lopes (Almeida et al., 2016), and Vigna Savi (Shamurailatpam et al., 2014). Differential amplification of heterochromatin was observed in all of the species analyzed in the present work, especially in A. gracile, which exhibited from 2 to 10 $\mathrm{CMA}^{+}$bands in different populations.

The phenomena responsible for variation in the heterochromatic portions of different plant species are not well known. The diverse CMA banding patterns observed in genera such as Caesalpinia L. sensu latu (Fabaceae) appear to be related to geographic distribution, ecological niches, and the phylogenetic relationships between the species (Van-Lume et al., 2017). The heterochromatic fraction in Anthurium is quantitatively variable among species and populations, and may be related to adaptive aspects, reflecting environmental or phylogenetic factors in those taxa. Corroborating this hypothesis, the population of $A$. gracile from Senhor do Bonfim in the semiarid region of Bahia showed large numbers of CMA bands (10) when compared to populations from the humid coastal areas of Paraíba and São Paulo (each with only one pair of bands). Chromosome studies involving larger numbers of species and populations, in conjunction with evolutionary phylogenetic methodologies, could aid in understanding the karyotypic diversity observed in Anthurium, one of the most diversified groups of Neotropical monocotyledons.

\section{Acknowledgments}

We thank the Conselho Nacional de Desenvolvimento Científico e Tecnológico (CNPq, Project Proc. n. 309215/2013-7) for the fellowship awarded to L.P.F and the doctoral fellowship awarded to S.N., the Coordenação de Aperfeiçoamento de Pessoal de Nível Superior (CAPES-Brasil, Finance code 101) for the doctoral fellowship awarded to J.M.P.C., and the Instituto Nacional do Semiárido (INSA) for support during collecting and travel. We especially thank Professor André Vanzela of the Universidade Estadual de Londrina for his critical revision of the text and suggestions.

\section{Conflict of interest}

The authors whose names are listed immediately below certify that they have no conflict of interest related to the article entitled "Chromosomal variability in Brazilian species of Anthurium Schott (Araceae): Heterochromatin, polyploidy, and B chromosomes".

\section{Author contributions}

SN analyzed cytogenetically all species and wrote the initial draft of the main text; MANC identified all species analyzed; JMPC analyzed the data and critically reviewed the final version of the manuscript; LPF conceived and designed the study. All authors read and approved the final version.

\section{References}

Almeida CCS, Carvalho PCL and Guerra M (2007) Karyotype differentiation among Spondias species and the putative hybrid Umbu-cajá (Anacardiaceae). Bot J Linn Soc 155:541547.

Almeida EM, Wanderley AM, Nollet F, Costa FR, Souza LGR and Felix LP (2016) A new species of Ameroglossum (Scrophulariaceae) growing on inselbergs in northeastern Brazil. Syst Bot 41:423-429.

Banaei-Moghaddam AM, Martis MM, Macas J, Gundlach H, Himmelbach A, Altschmied L, Mayer KFX and Houben A (2014) Genes on B chromosomes: Old questions revisited with new tools. Biochim Biophys Acta 1849:64-70.

Camacho JPM, Sharbel TF and Beukeboom LW (2000) B-chromosome evolution. Philos Trans R Soc Lond B Biol Sci 355:163-178.

Carlsen M and Croat TB (2013) A molecular phylogeny of the species-rich Neotropical genus Anthurium (Araceae) based on combined chloroplast and nuclear DNA. Syst Bot 38:576-588.

Carvalheira GMG, Guerra M, Santos GA, Andrade VC and Farias MCA (1991) Citogenética de angiospermas coletadas em Pernambuco-IV. Acta Bot Brasilica 5:37-51.

Carvalho R, Soares-Filho WS, Brasileiro-Vidal AC and Guerra M (2005) The relationships among lemons, limes and citron: A chromosomal comparison. Cytogenet Genome Res 109:276-282.

Coelho MAN and Mayo SJ (2007) Typifications of names of Brazilian taxa of Anthurium sect. Urospadix (Araceae). Taxon 56:211-225.

Coelho MAN, Mayo SJ and Waechter JL (2009) Revisão taxonômica das espécies de Anthurium (Araceae) seção Urospadix subseção Flavescentiviridia. Rodriguesia 60:799-864.

Cordeiro JMP, Kaehler M, Souza G and Felix LP (2017) Karyotype analysis in Bignonieae (Bignoniaceae): chromosome numbers and heterochromatin. An Acad Bras Cienc 89:2697-2706

Cordeiro JMP, Nollet F, Buril MT, Chase MW and Felix LP (2018) A new species of Gomesa (Oncidiinae, Orchidaceae) from inselbergs in Brazilian caatinga: Morphological and karyological evidence. Phytotaxa 374:147-154.

Cotias-de-Oliveira ALP, Guedes MLS and Barreto EC (1999) Chromosome numbers for Anthurium and Philodendron spp. (Araceae) occurring in Bahia, Brazil. Genet Mol Biol 22:237-242.

Croat TB (1986) A revision of genus Anthurium (Araceae) of Mexico and Central America. Part II: Panama. Monogr Syst Bot 14:1-204.

Croat TB and Sheffer RD (1983) The sectional groupings of Anthurium (Araceae). Aroideana 6:85-123

Cusimano N, Bogner J, Mayo SJ, Boyce PC, Wong SY, Hesse M, Hetterscheid WLA, Keating RC and French JC (2011) Relationships within the Araceae: Comparison of morphological patterns with molecular phylogenies. Am J Bot 98:654-668.

D'Ambrosio U, Alonso-Lifante MP, Barros K, Kovarík A, Xaxars GM and Garcia S (2017) B-chrom: A database on B-chromosomes of plants, animals and fungi. New Phytol 216:635-642.

Gonçalves EG (2005) A new species of Anthurium (Araceae) from Espírito Santo State, Eastern Brazil. Feddes Repert 116:92-95. 
Gonçalves EG and Jardim J (2009) Two new species of Anthurium (Araceae) from Serra do Teimoso, Bahia, Brazil. Kew Bull 64:713-717.

Guerra M (1986a) Reviewing the chromosome nomenclature of Levan et al. Rev Bras Genet 9: 741-743.

Guerra M (1986b) Citogenética de Angiospermas coletadas em Pernambuco, I. Rev Bras Genet 9:21-40.

Guerra M (2000) Patterns of heterochromatin distribution in plant chromosomes. Genet Mol Biol 23:1029-1041.

Guerra MS and Souza MJ (2002) Como observar cromossomos: Um guia de técnicas em citogenética vegetal, animal e humana. FUNCEC, Recife, 131 pp.

Haigh A, Mayo SJ and Coelho MAN (2011) Four new species of Anthurium (Araceae) from Bahia, Brazil. Kew Bull 66:123132.

Houben A, Banaei-Moghaddam AM and Klemme S (2013) Biology and evolution of B chromosomes. In: Leitch IJ, Greilhuber J, Doleel J and Wendel JF (eds) Physical Structure, Behaviour and Evolution of Plant Genomes. Plant Genome Diversity Volume 2. Springer-Verlag, Wien, pp 149-165.

Houben A, Banaei-Moghaddam AM, Klemme S and Timmis JN (2014) Evolution and biology of supernumerary B chromosomes. Cell Mol Life Sci 71:467-478.

Jones N and Houben A (2003) B chromosomes in plants: Escapees from the A chromosome genome? Trends Plant Sci 8:417-423.

Lamb JC, Yu W, Han F and Birchler JA (2007) Plant chromosomes from end to end: Telomeres, heterochromatin and centromeres. Curr Opin Plant Biol 10:116-122.

Levin DA, Palestis BG, Jones RN and Trivers R (2005) Phyletic hot spots for B chromosomes in angiosperms. Evolution 59:962-969.

Lockwood JD, Aleksic JM, Zou J, Wang J, Liu J and Renner SS (2013) A new phylogeny for the genus Picea from plastid, mitochondrial, and nuclear sequences. Mol Phylogenet Evol 69:717-727.

Madlung A (2013) Polyploidy and its effect on evolutionary success: Old questions revisited with new tools. Heredity 110:99-104.

Marchant CJ (1973) Chromosome variation in Araceae: V* Acoreae to Lasieae. Kew Bull 28:199-210.

Marutani M and Kamemoto H (1983) Transmission and significance of B Chromosomes in Anthurium warocqueanum. Am J Bot 70:40-46.

Marutani M, Sheffer RD and Kamemoto H (1993) Cytological analysis of Anthurium andraeanum (Araceae), its related taxa and their hybrids. Am J Bot 80:93-103.

Oliveira IG, Moraes AP, Almeida EM, Assis FNM, Cabra JS, Barros F and Felix LP (2015) Chromosomal evolution in Pleurothallidinae (Orchidaceae: Epidendroideae) with an emphasis on the genus Acianthera: chromosome numbers and heterochromatin. Bot J Linn Soc 178:102-120.

Patterson TB and Givnish TJ (2003) Geographic cohesion, chromosomal evolution, parallel adaptive radiations, and consequent floral adaptations in Calochortus (Calochortaceae): Evidence from a cpDNA phylogeny. New Phytol 161:253264.

Petersen G (1989) Cytology and systematics of Araceae. Nord J Bot 9:119-166.
Ramsey J and Ramsey TS (2014) Ecological studies of polyploidy in the 100 years following its discovery. Philos Trans R Soc Lond B Biol Sci 369:20130352.

Rice A, Glick L, Abadi S, Einhorn M, Kopelman NM, SalmanMinkov A, Mayzel J, Chay O and Mayrose I (2015) The Chromosome Counts Database (CCDB) - a community resourse of plant chromosome numbers. New Phytol 206:19-26.

Scholthof KG, Irigoyen S, Catalan P and Mandadi KK (2018) Brachypodium: A monocot grass model genus for plant biology. Plant Cell 30:1673-1694.

Shamurailatpam A, Madhavan L, Yadav SR, Bhat KV and Rao SR (2014) Heterochromatin characterization through differential fluorophore binding pattern in some species of Vigna Savi. Protoplasma 252:629-635.

Sheffer RD and Croat TB (1983) Chromosome numbers in the genus Anthurium (Araceae) II. Am J Bot 70:858-871.

Sheffer RD and Kamemoto H (1976) Chromosome numbers in the genus Anthurium Am J Bot 63:74-81.

Soltis DE, Visger CJ and Soltis PS (2014) The polyploidy revolution thenand now: Stebbins revisited. Am J Bot 101:10571078.

Stebbins GL (1971) Chromosomal evolution in higher plants. Edward Arnold, London, 216pp.

Van-Lume B, Esposito T, Diniz-Filho JAF, Gagnon E, Lewis GP and Souza G (2017) Heterochromatic and cytomolecular diversification in the Caesalpinia group (Leguminosae): Relationship between phylogenetic and cytogeographical data. Perspect Plant Ecol Evol Syst 29:51-63.

Viégas J, Coelho MN, Corrêa MGS and Corrêa LB (2006) Taxonomic and cytogenetic analysis of species of the Anthurium (Araceae) genus native to the Brazilian Atlantic Forest. Floriculture, Ornamental and Plant Biotechnology Volume IV. Global Science Books, London, 695 pp.

\section{Internet Resources}

Boyce PC and Croat TB (2011) The Überlist of Araceae, Totals for Published and Estimated Number of Species in Aroid Genera, http://www.aroid.org/genera/180211uberlist.pdf.

Brent DC, McDavid W and Greer D (2008) Uthscsa. Image Tool (IT) - Version 3.0., http://ddsdx.uthscsa.edu/dig/download.html (accessed on 10 April 2017).

Coelho MAN, Soares ML, Calazans LSB, Gonçalves EG, Andrade IM de, Pontes TA, Sakuragui CM, Temponi LG, Buturi C and Mayo S (2018) Araceae. In: Forzza RC (coord) Lista de Espécies da Flora do Brasil. Jardim Botânico do Rio de Janeiro, http://floradobrasil.jbrj.gov.br/jabot/floradobrasil/FB51 (accessed 16 July 2018).

Govaerts R, Bogner J, Boos J, Boyce P, Cosgriff B, Croat T, Gonçalves E, Grayum M, Hay A, Hetterscheid W et al. (2016) World checklist of Araceae. Facilitated by the Royal Botanic Gardens, Kew, http://apps.kew.org/wcs.

\section{Associate Editor: Marcelo Guerra}

License information: This is an open-access article distributed under the terms of the Creative Commons Attribution License (type CC-BY), which permits unrestricted use, distribution and reproduction in any medium, provided the original article is properly cited. 